\title{
Who wants to terminate the game? The role of vested interests and metaplayers in the ATOLLGAME experience
}

\author{
Anne Dray \\ Australian National University, Australia \\ Pascal Perez \\ CIRAD, France \\ Australian National University, Australia \\ Christophe Le Page \\ CIRAD, Thailand \\ Patrick D'Aquino \\ CIRAD, New Caledonia \\ Ian White \\ Australian National University, Australia
}

\begin{abstract}
Low coral islands are heavily dependent on groundwater for freshwater supplies. The declaration by the government of Kiribati of water reserves over privately owned land has led to conflicts, illegal settlements, and vandalism. Also, the water consumption tends to increase toward Western-like standards, and human pollution has already contaminated most freshwater lenses. This project aims to provide relevant information to local stakeholders to facilitate dialogue and devise sustainable water management practices. A computer-assisted role-playing game is implemented to fulfill this aim. The following three-stage methodology is applied: collecting local and expert knowledge, blending the different viewpoints into a game-based model, and playing the game with the different stakeholders to explore different scenarios. Although game sessions delivered successful outcomes, the final stage of the project is characterized by the upheaval of contradictory government stands that undermine the whole process. It is argued that heterogeneous viewpoints may be handled in a satisfactory manner during the gaming sessions but that longterm hidden agendas may override the outcomes. Beyond the inherent question of legitimacy attached to such approaches, some players clearly must deal with constraints that are often genuinely considered external to the ongoing negotiation process.
\end{abstract}

KEYWORDS: ATOLLGAME; contamination; coral islands; dialogue; freshwater reserves; groundwater; role-playing game; companion modeling; entrenched agendas; water management; multiagent system; participation; pollution; poverty alleviation; sustainable development; Pacific; staged process; Tarawa; water demand; water reserves; water management strategies

AUTHORS' NOTE: We wish to thank Agence Française de Développement and the Australian Centre for International Agricultural Research for their financial support of this study.

SIMULATION \& GAMING, Vol. X No. X, Month XXXX xx-xx

DOI: $10.1177 / 1046878107300673$

(C) Sage Publications 
Many low coral islands depend on groundwater for freshwater supplies. The availability, quality, and management of groundwater are central to sustainable development and poverty alleviation in small island nations. Increasing populations, growing per capita demand, and restricted land areas limit water availability and generate conflicts, particularly over the use and protection of groundwater sources (Falkland \& Brunel, 1993).

This study was carried out on the low-lying Tarawa atoll, Republic of Kiribati, in the central Pacific Ocean (see Figure 1). Unconfined groundwater resources used to supply the reticulation system are located in freshwater lenses on the largest islands of the atoll. The water table is typically 0.8 to $1.6 \mathrm{~m}$ below ground. South Tarawa is the capital and main population center of the republic. The pollution generated by its 45,000 inhabitants has already contaminated several freshwater lenses. Hence, the reticulated water supply for South Tarawa's inhabitants is pumped from horizontal infiltration galleries in groundwater protection zones with restricted access called "water reserves," on Bonriki and Buota islands, in the southeast of Tarawa atoll. Settlements on water reserves are restricted. The reticulation system provides freshwater to island communities along South Tarawa. Water abstraction and supply for South Tarawa are controlled by the Public Utility Board (PUB), which is government owned. Water is regulated by the Ministry of Works and Energy, the Ministry of Health, and the Ministry of Environment.

The combined sustainable yield of the Bonriki and Buota water reserves is about $1,750 \mathrm{~m}^{3} /$ day, equivalent to about $30 \mathrm{~L}$ per capita per day of freshwater, representing $60 \%$ of the needs of South Tarawa's communities (White et al., 2002). The per capita water demand is increasing as more water-using devices are introduced. This and the population growth rate of about $5 \%$ threaten the sustainability of the groundwater exploitation system. With losses estimated at $50 \%$, the reticulated system is unable to meet the demand. Water is therefore supplied for only a few hours per day as a de facto demand management tool. Under the Asian Development Bank's Sanitation, Public Health and Environment (SAPHE) project, water demand was to be controlled by supplying each household with a small fixed-volume storage tank, which is filled by a trickle feed once per day. Only a limited number of households have adopted rain-harvesting technologies. Unfortunately, roof installations are often poorly managed or difficult to set up with thatched roof houses (Carpenter, Stubbs, \& Overmars, 2002).

Traditional domestic water wells remain an essential source of freshwater, although they are anything but reliable. They are excavated close to dwellings, very often near to the lagoon-side shore. During extended drought spells, saltwater intrusion occurs, and the wells become increasingly brackish. In addition, pollution from surface sources, such as waste from domestic pigs, can compromise water quality in domestic wells.

Landownership and traditional land-use rights are central issues in many small island communities. Land provides groundwater, food, building materials, attendant fishing rights, and cash income from copra harvesting (Jones, 1997). Traditional landownership includes groundwater resources, a fact poorly appreciated when 


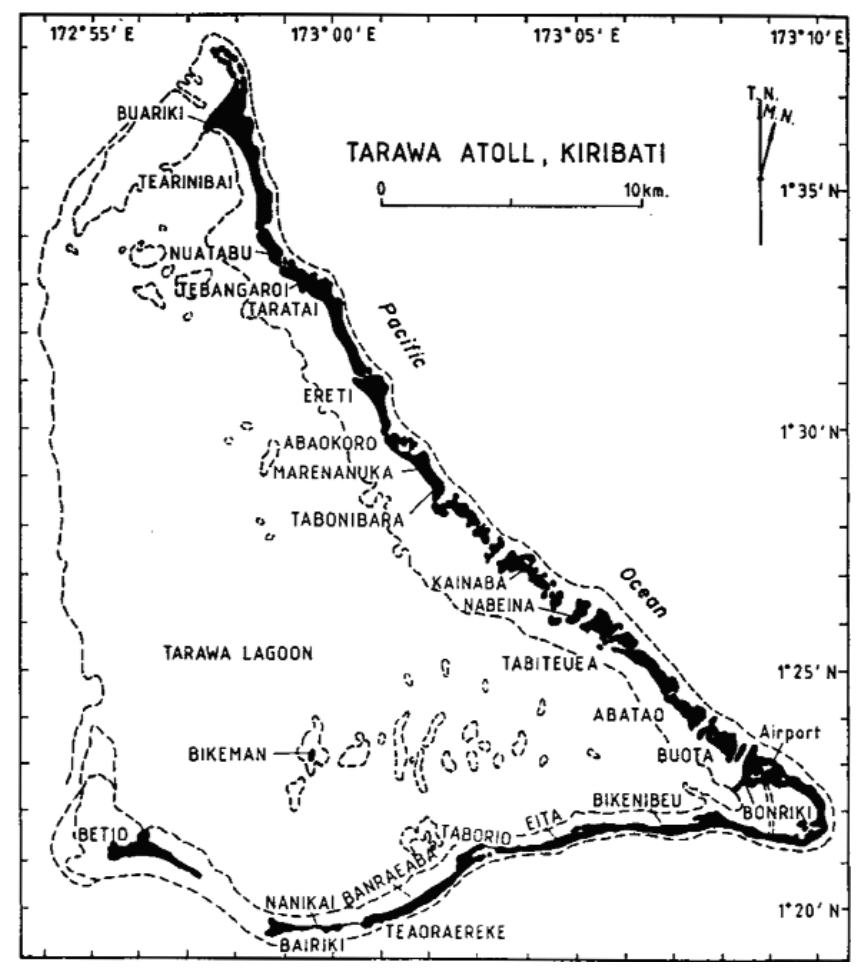

FIGURE 1: Tarawa Atoll

NOTE: Bonriki and Buota islands are on the lower right of the atoll.

water reserves were established. The creation of water reserves has led to conflicts between traditional landowners and government authorities and to illegal settlements and vandalism of public assets (White et al., 1999). The payment of adequate compensation or rent and the restriction of settlement on the reserves are continuing contentious issues. Wider communities tend to regard designated water reserves as sources for common-pool resources, such as coconuts, sand, gravel, and building materials, which can be easily plundered. In addition, landowners of areas designated as water reserves continue to claim that groundwater has seriously affected coconut and swamp taro productivity, although measurements show otherwise (White \& Falkland, 2004).

\section{Future water sources}

In 1999, the government of Kiribati obtained a loan from the Asian Development Bank to finance the $\$ 10.24$ million SAPHE project. This project aims to improve the 
freshwater reticulation, sanitation, and waste disposal systems on South Tarawa. It is driven by a steering committee involving the PUB, the Ministry of Works and Energy, the Ministry of Environment, Ministry of Finance, Ministry of Health, and the Lands Department.

Part of the plan for the improvement of freshwater supply was to improve water abstraction from the existing reserves in South Tarawa and to seek additional groundwater sources in North Tarawa. Comprehensive groundwater investigations were conducted on two islands immediately north of Bonriki and Buota, Abatao and Tabiteuea, to identify the extent of the freshwater lenses and to provide estimates of the sustainable water yields. Previous reports had stressed the importance of first fully exploiting water resources in South Tarawa and second taking account of the costs and social impacts of any new water reserves to avoid the problems encountered on Bonriki and Buota. Although social studies were conducted, these were aimed mainly at public education. Contrasting viewpoints arose within the SAPHE Steering Committee over the costs and social impacts of water resource development in North Tarawa compared with additional development of the existing reserves in South Tarawa.

\section{Aims of this work}

The Ministry of Works and Energy, together with PUB, supported trials of new participatory approaches to lessen conflicts over water resources. Our work aims to provide relevant information to local, institutional, and community representatives to facilitate dialogue and to explore together sustainable and equitable water management practices. A role-playing game (RPG) coupled with a computer-based simulator of the water supply and community systems was developed to assist in these tasks. This coupled approach provides a powerful means for studying interactions between societies and their environment (Bousquet et al., 2002). It has the capacity to promote discussion among stakeholders with contrasting and conflicting viewpoints (D'Aquino, Le Page, Bousquet, \& Bah, 2003). The success of the approach inherently rests on the ability of various players to identify their own mental constructs with the game's features. It appears essential to encompass stakeholders' viewpoints within RPGs. However, Becu, Bousquet, Barreteau, Perez, and Walker (2003) showed that it was anything but trivial to use knowledge elicitation techniques to infer formal ontologies.

Dray et al. (2006) described the methodology developed to collect, understand, and merge the viewpoints of different stakeholders to build a shared representation of a system through a conceptual model using unified modeling language. The application of a semiautomatic process, using qualitative analysis software, makes it possible to create a collective and consensual representation based on unified modeling language of a system from individual and fragmented narratives. This common representation is used to build the essential elements of an RPG, while conflicting issues are incorporated into the flexible design of the playing sessions. This article first focuses on the conception of the RPG and explores the outcomes, successes, failures, and limitations of the game and the factors involved. 


\section{Conception of the computer-assisted RPG}

\section{Conceptual framework}

The RPG is designed as a medium of communication based on the existing conceptual model of the water supply system and the attendant social and institutional interactions (Perez, Dray, White, Le Page, \& Falkland 2003). It is designed to commence or develop communication between stakeholders. In a well-designed RPG, players are aware of the range of issues at stake but are allowed to express their views and behave according to their beliefs. Another fundamental characteristic is the ability of the RPG to generate collective scenarios that will explore new management avenues. To achieve these tasks, the RPG must meet the following criteria:

- It must represent simplified features and processes encountered in reality. In particular, biophysical processes, social interactions, and spatial descriptions should be understood and accepted by all players as plausible representations.

- It must secure, at every stage of the game, the neutrality of the selected rules and of the game master's decisions. This "fair game" is instrumental in helping players build selfconfidence and advocate their viewpoints.

- It must create opportunities for players to comment on, modify, and improve the rules. Indeed, the game is intentionally designed with a rudimentary set of rules that needs improvement. Players move progressively from playing against one another to a situation in which they appropriate the game collectively.

- Finally, when players have realized the collective benefit of the game, they tend to explore more complex situations and to implement many more rules. Most of the time, the increasing complexity tends to merge the RPG and the real situation. A key strategy in this approach is to give stakeholders the capacity to build their future together. Manipulation, lobbying, and struggles for power are inherently part of the process, but in a nonthreatening and controlled environment.

\section{Game boards and virtual landscape}

The set of the game is composed of two maps displayed on two separated tables. Both maps represent a 32.4-ha virtual island, each displayed on a $25 \times 45$ regular spatial grid with hexagonal cells. Each unit land cell corresponds to a $490-\mathrm{m}^{2}$ land area. Concurrently, a similar computer-based environment is created with VisualWorks, using the CORMAS platform (Bousquet, Bakam, Proton, \& Le Page, 1998). These environments include generic features without direct references to actual islands to avoid any threats to players.

Island 1 (Figure 2) corresponds to a scarcely populated island (50 families) from which the government is already pumping freshwater. The water reserve is delineated with a red line, and horizontal pumping galleries are explicitly represented. Island 2 (Figure 2) corresponds to an overcrowded island (200 families), where groundwater is already polluted, so that the island must be supplied with a distribution pipe for reticulating drinking water pumped from Island 1. 


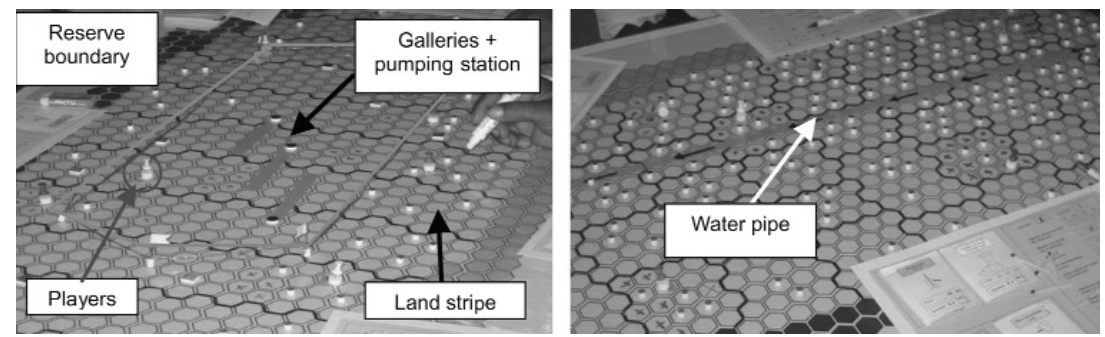

FIGURE 2: Island 1 (left) and Island 2 (right)

\section{Water balance and hydrogeological models}

Biophysical processes and land-use dynamics are encapsulated into the computerbased simulator. The screen-displayed information is available at any time for the players to check their personal situations or to compare with others.

According to the field interviews, freshwater lenses were perceived as global, monolithic resources on each island. Rainwater infiltration into the soil was acknowledged by a majority of interviewees. Runoff was not an issue because of the very high permeability of the coral-sand soils. Water uptake by vegetation and evapotranspiration were far less understood. Therefore, we opted for a simple reservoirlike water balance model for our computer-based simulator. The model, called WATBAL (Falkland, 1992), uses three storage reservoirs and 10-day values of rainfall and potential evapotranspiration. The first reservoir is the vegetation interception of rainfall, the second reservoir represents the unsaturated soil storage, and the third reservoir corresponds to the freshwater lens. Recharge of the lens occurs only after plants have satisfied their water requirements. Pumping galleries, traditional wells, and coconut trees extract water directly from the lens. Using the cellular automata capacities of our simulator, the water balance is calculated for each cell, allowing both the spatial heterogeneity of the processes and their time dependence to be taken into account.

The shape and the depth of the freshwater lens are calculated according to the steady-state model proposed by Volker, Mariño, and Rolston (1985). This model predicts the depth of the freshwater lens and the thickness of the transition zone from the recharge and uptake values, according to the radius of the lens in a circular island. Two strong assumptions limit the use of this simple 2D model: (a) the recharge is constant, and (b) the lens is in a steady-state condition. The model is often used for long-term predictions on the basis of long-term averaged data. This 2D model was modified into a 3D-like simulator using the isotropic properties of the mesh (Perez et al., 2003). To do so, some cells were selected and designated as lens nuclei, surrounded by concentric circles of isopiezometric cells (Figure 3). The orthogonal distance between the lagoon and ocean shores crossing a nucleus gives 

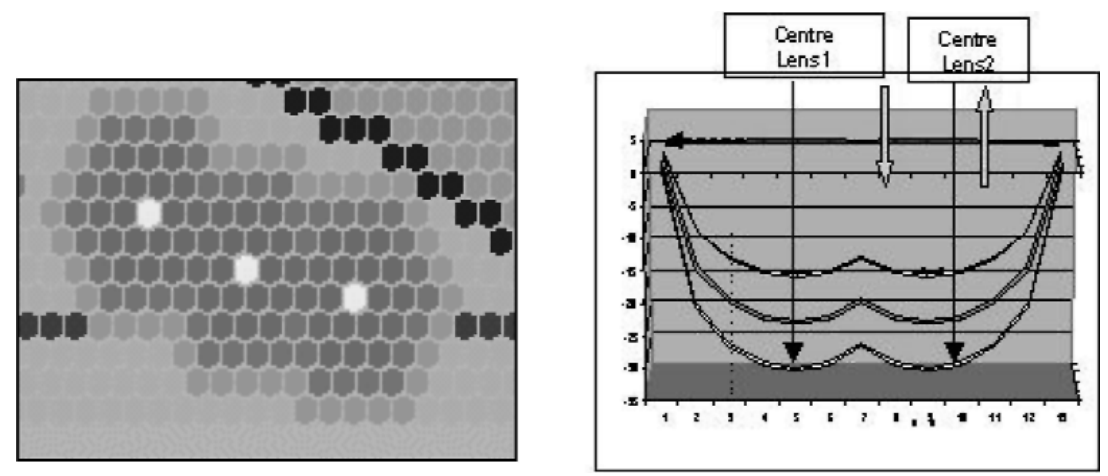

FIGURE 3: Nuclei and Izopiezometric Cells (left) and Corresponding Representation of the Volume of a Freshwater Lens (right)

the value of the corresponding radius (L). The elongated lens is approximated by a succession of these elementary units. The global volume of the lens corresponds to overlapping bowls (Figure 3).

For a given cell, the freshwater thickness is given by the attribute depth. The hydrogeological model calculates each individual depth after averaging inputs and outputs over the whole freshwater lens. This depth attribute is then used to specify the water quality by updating the cell's attribute "wellWaterQuality" according to a simple rule: If the depth is less than $1.6 \mathrm{~m}$, the water is considered salty, and if the depth is greater than $3.1 \mathrm{~m}$, the water is considered fresh. In between, the water is declared brackish. This salinity index is visually accessible to the players at any time (Figure 4).

\section{Players}

From the field interviews, the connection between land tenure issues and water management was a paramount element in the negotiations with the government. Population increases, particularly through immigration from less developed outer islands, were perceived as a threat in terms of water consumption, groundwater pollution, and pressure on the land. Usually, these migrants are related to landowners in South Tarawa. It was therefore decided to design the game around conflicting rules for land and water allocation. Each player, at the beginning of the game, becomes a local landowner and must accommodate an increasing number of incoming settlers.

Each game board has 8 players, to facilitate player interactions on each island. This even number of players does not respect the real population densities in North Tarawa and South Tarawa, which would have led to allocating 1 player on Island 1 for every 10 players on Island 2. However, these differences were taken into account on the game boards and in the simulator with the creation of household entities, which were unevenly distributed among the two islands. Household entities are 

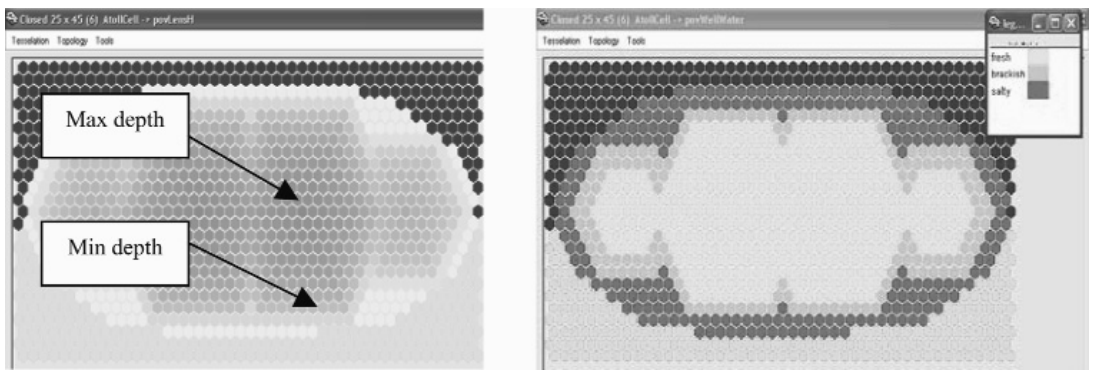

FIGURE 4: Plan Views of the Lens Depth (left) and the Corresponding Salinity Index (right)

represented by red pawns on the game boards. The corresponding agents in the computer-based simulator are divided into landowners or relatives. Fifty household entities are created on Island 1 (11 landowners and 39 relatives) and 200 on Island 2 (42 landowners, 158 relatives). The initial location of the agents is saved in the computer-based environment. The main attributes of each household entity are the size of the family, the water requirements, a list of equipment needed for water (pump, rainwater tank, or PUB fixed-volume water supply tank), and a consumption satisfaction index.

Field interviews with landowners also showed that financial issues linked with water management mainly dealt with land leases and investment in equipment but seldom with water pricing. Thus, it was necessary to allocate different types of income to the players to accommodate these issues. On the basis of population census data, we decided on the following employment distribution: On Island 1, one player is a public servant, three are seamen, and four are unemployed. On Island 2 the distribution is slightly different: three players are public servants, three are seamen, and two are unemployed. At the beginning of each round, players are given tokens representing their respective incomes. On the basis of economic data collected from our field surveys, income allocation follows a proportional calibration: two for unemployed, four for seamen, and six for public servants. The relatives settling on their land can cost the players money or provide some additional income. The present version of the computer-based simulator does not take into account these financial processes.

At the beginning of the game, each player randomly draws a card that defines his or her personal profile in the game: land location, type of job, and family size. All materials used during the game are bilingual (English and I-Kiribati).

\section{Players' objective}

Players are given the task of providing enough good-quality water to their families in each round. Their individual objective is to minimize the number of angry 
or sick people in their houses. People become angry when they do not have enough water to drink, and they become sick if they drink unhealthy water. Unhealthy water in the game is water that is salty or polluted. Spatially distributed salinization processes are calculated and displayed by the computer-based simulator. Because pollution processes remain a source of conflict between stakeholders, it was decided to introduce them as an arbitrary pollution event during the game.

To provide drinking water to their families, players are given buckets at the beginning of the game. One bucket can store $20 \mathrm{~L} /$ day, roughly equivalent to daily individual needs. On purpose, the initial number of buckets is lower than the players' needs. Thus, they must buy equipment (pumps, rainwater tanks, or PUB fixedvolume storage tanks) that will increase their storage capacity. Usually, the rainwater tanks automatically refill at the end of each round. But if rainfall during the round was not sufficient, the rainwater tanks remain empty. The same happens with the PUB tanks if the distribution pipe cannot provide enough water during the round.

Players can decide to farm vegetable gardens to increase their incomes, provided they have enough money and sufficient water storage capacity for irrigation at each round. The profit from a crop depends on the climate. If the round was dry, a crop fails and there is no extra income.

Within the computer-based simulator, household entities follow the same decision rule: They satisfy their drinking water needs from their rainwater tanks or PUB connections, if any, and supply their other domestic water demands from their wells. If they have only wells, they use them for both purposes, taking the risk to drink possibly unhealthy water. The individual water availability is updated at each time step according to the type of equipment. Groundwater extraction from individual wells is limited by a maximum depletion rate in the vicinity of the well.

\section{Duration}

The game consists of two sessions of four rounds, each equivalent to a 90-day (approximately 3-month) season. The first and third rounds correspond to a good rainy season $(550 \mathrm{~mm})$ and the second and fourth rounds to a dry season $(190 \mathrm{~mm})$. Initially, on Island 1, the pumping rate from the government is steady and corresponds to $150 \mathrm{~m}^{3} /$ day. On Island 2, the government provides local residents $150 \mathrm{~m}^{3} /$ day through the distribution pipe. The 90-day season was chosen to be consistent with the hydrogeological model, because the computer-based simulator ran on a 10-day timestep basis. One round in the game accounts for nine time steps in the model.

\section{Playing rounds}

During the first session, dedicated to individual strategies, players must accommodate new relatives on their land (Figure 5) and adjust their incomes correspondingly. According to their available cash, they may choose to invest in new water equipment and/or decide to plant crops. The rainfall influences groundwater salinity, storage in rainwater tanks, and crop yields. This session allows players to perceive 


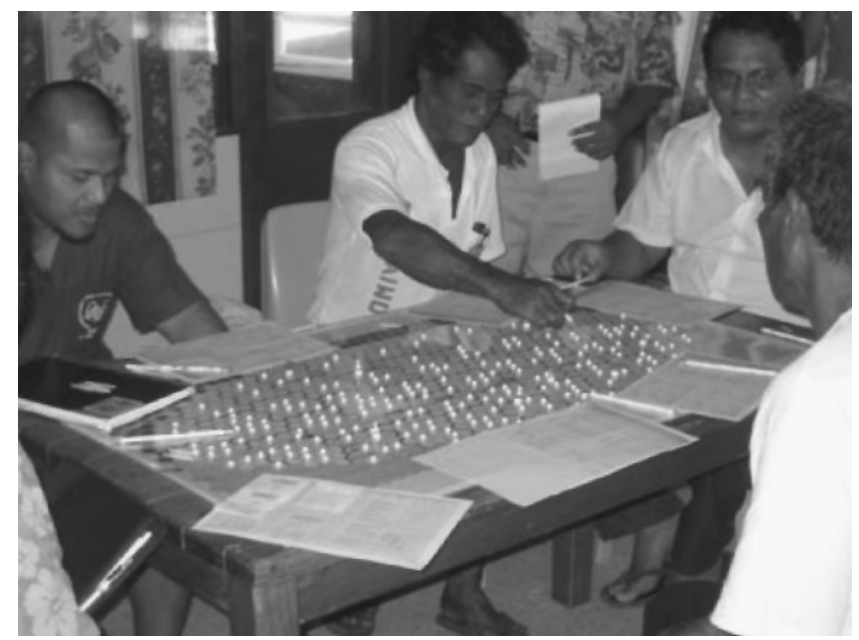

FIGURE 5: Players on Island 2 Accommodating New Relatives Settling on Their Island

the impact of the location of domestic wells on their wells' water quality: The closer to the lagoon or ocean side, the saltier groundwater becomes during drought periods.

At the end of the first session, one player on Island 1 is given the opportunity to sell part of his or her land to a new (virtual) settler, who can accept or reject the sale offer. At the same time, on Island 2, one player is given the opportunity to leave his or her land and to relocate to Island 1 if he or she can buy land from another player on that island. This introduces the first interaction between the two tables.

The second session is dedicated to collective decision making. First, the game master introduces one collective event card on each island. On Island 1, the card indicates that the government has decided to remove all settlers and crops located on the reserve. Players must relocate their relatives, and they lose the removed crops. On Island 2, the card indicates that the government has decided to raise a water connection fee from each dwelling connected to the pipe. One player, selected randomly, is given the task to fulfill the government decisions. This player leaves his "landowner" role and becomes a "water agency" player. As such, he or she freely negotiates with players on both islands. This player's task is expanded with the introduction, in the second round, of an event on Island 2: Because of financial issues, the government cannot properly maintain the distribution pipe. As a consequence, the discharge falls to $75 \mathrm{~m}^{3} / \mathrm{day}$. Another event is introduced on Island 1 during the third round: Because of the water shortage on Island 2, the government decides to increase the pumping rate from $150 \mathrm{~m}^{3} /$ day to $250 \mathrm{~m}^{3} /$ day.

Within the computer-based simulator, the AgentPUB entity represents the water agency in charge of the water extraction and distribution. The AgentPUB controls the volume of water pumped from Island 1 and transferred to Island 2. The initial 
pumping rate on Island 1 is adjusted according to the demand. The distribution on Island 2 is driven by the household entity's position along the pipe.

\section{Implementation of the computer-assisted RPG}

\section{Convocation}

A 2-day workshop held on Tarawa in April 2004 gathered 16 representatives: 1 from the PUB, 1 from the Ministry of Environment, 1 from the SAPHE project office, 1 from the Lands Department, and 3 villagers each from Bonriki, Buota, Abatao, and Tabiteuea. The project team included two table assistants, one game master, two recording assistants, and one computer assistant.

Representatives of the four islands were selected after a series of meetings organized jointly by the local councilors and our team leader in Tarawa. Selections were handled entirely by the local communities, taking into account only two requests from our project team: (a) selecting outspoken individuals and (b) selecting those expressing contrasting viewpoints within the community. A formal invitation was sent to members of the SAPHE Steering Committee and project office. They were given the choice to come themselves or to delegate the task to other representatives of their ministry. Only one of four (the SAPHE project manager) came; all others chose to delegate.

\section{Outcomes}

Representatives from the different islands displayed different viewpoints about the water reserves. Group meetings organized in the villages prior to the workshop fostered a very open debate. On the institutional side, the positions of the different officers attending the workshop demonstrated a clear commitment to the project. All participants showed the same level of motivation either to express their views on the issue or to genuinely try to listen to other viewpoints. Participants also agreed to follow the rules proposed by the game master, especially the necessity to examine problems from a broader perspective.

During the first session, the players quickly handled the game and entered into interpersonal discussions and comparisons. The atmosphere was good, and the game seemed interesting enough to maintain the participants' interest. Most players found that individual strategies were strongly dependent on environmental uncertainties. Interaction between the two tables started when one player from the Island 2 was given the opportunity to move to Island 1 . The bargaining process that emerged from this new situation illustrated the actual tensions existing around the land tenure market. It was a very powerful demonstration for all players of the intricacies between migratory pressure, monetized land value, and access to water. So far, despite factual evidence, these issues have been largely dismissed in the reality by an official discourse based on traditional customs and uses.

On the second day, the introduction of a water agency and the selection of its director created a little tension among the participants. However, the players came to 


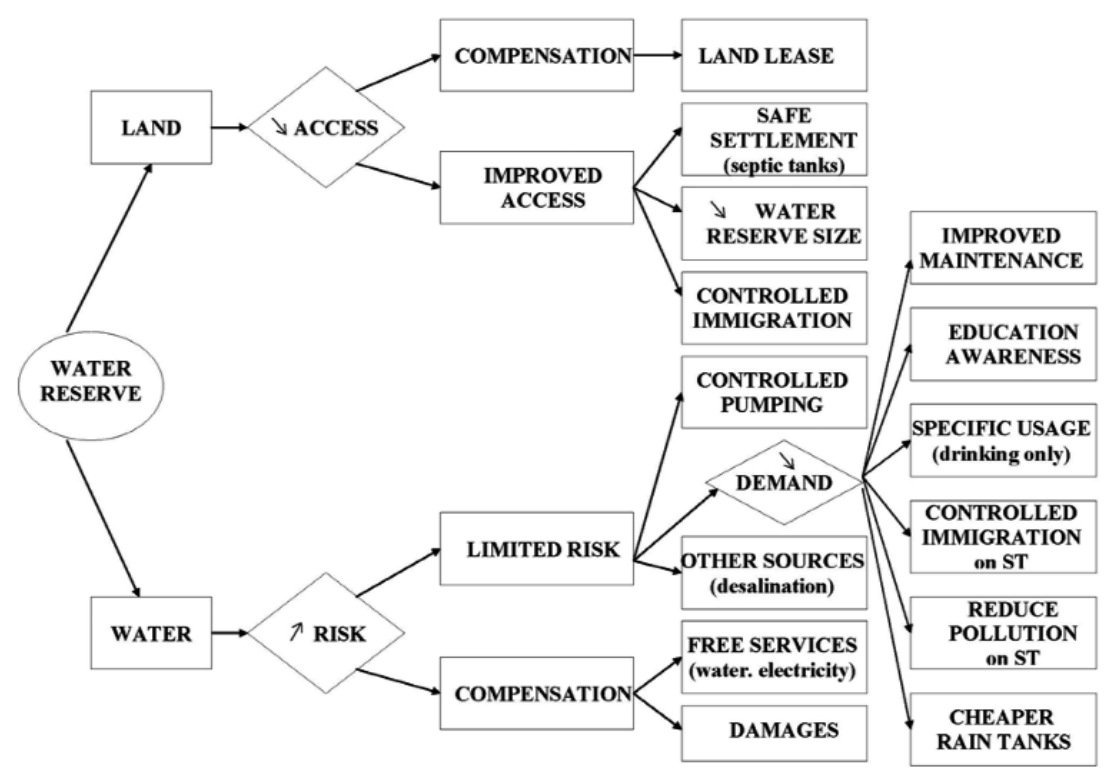

FIGURE 6: Flowchart of Financial, Technical, and Social Solutions Devised by the Game Players

accept the new situation as a scenario in the game and started to interact with the newly created institution. On Island 1, the decision to remove crops and settlers from the water reserve immediately generated animated discussions among players. On Island 2, the recovery of service fees from the players connected to the distribution pipe had the same effect. At that stage, players started to merge arguments based on the game with others coming directly from the real situation. On Island 1, players entered direct negotiations with the director of the water agency. On Island 2, discussions involved players willing or not willing to pay the fee.

Finally, the game master introduced the fact that the water agency was no longer able to maintain the reticulated system because of poor recovery of the service fees. This dramatically decreased the quantity of water offered on Island 2. At this stage, all players gathered around Island 1 and entered a collective debate on the water reserve management. Consequently, players were asked to go back to their tables and to list solutions to improve the situation on their islands. When the two lists were completed, the game master assisted the participants to build a flowchart of financial, technical, and social solutions (Figure 6), taking into account issues from both islands.

\section{Exploring scenarios for solutions}

A collective analysis of the flowchart concluded that the actual situation was largely unsustainable either from a financial or social viewpoint: 
- The government relies on the land leases (top part of the flowchart) to secure social acceptance of the water reserves. The land market has already pushed land prices to levels that cannot be matched by current government leases. In addition, other possible technical solutions (desalination plants, improved distribution) are not yet directly linked with the water exploitation issues on the islands.

- Some local residents claim that the perceived environmental risks, such as the decreased yield of coconuts, created by the pumping in the water reserves should be compensated for as well. These damages (bottom part of the flowchart) should be paid to all the permanent residents of the island, aside from the land leases granted to the water reserve landowners. However, fewer claims were made for the negotiated and regulated use of the water reserves, weakening somewhat the environmental risk claim.

The flowchart in Figure 6 provides a set of interdependent solutions that should be explored to gradually address the present situation. Whether applied to already existing or potential water reserves, the following guidelines are relevant:

- The financial solutions could be aided with technical solutions, including regulated access to the water reserves or the participatory management of pumping.

- The water exploitation issues could be more strongly linked with the water distribution issues and eventually with sanitation issues (however, sanitation issues are generally disconnected from the others by most people).

- Exploring the middle part of the flowchart would enable more "consensual" stakeholders to participate in negotiations that are presently dominated by more extremist views.

- Management issues on the existing water reserves (on Bonriki and Buota) and implementation issues on the potential ones (on Abatao and Tabiteuea) are inherently interrelated. On one side, creating new water reserves without addressing the actual problems on the existing ones will perpetuate problems. On the other side, the introduction of new actors in the debate may help reduce the actual bipolar confrontation between landowners and the government on the existing water reserves.

\section{Discussion and perspectives}

\section{Instant debriefing}

At the end of the 2-day workshop, the project team held what we called an "instant debriefing." Beyond our satisfaction of having conducted a playful and fruitful exercise, our analysis focused on ways to transform the scenario flowchart into a viable road map for the government. Careful study of the memos (videos, notes, and game spreadsheets) revealed the existence of two types of strategic behavior among players that would strongly influence the outcomes.

Final discussions around the flowchart were hijacked by a minority of pseudoplayers. These were local stakeholders who came with strong and fixed agendas and tried to enforce their views throughout the game. As requested, they were indeed outspoken representatives, but they were not prepared to compromise. The RPG did not modify their positions, and, for example, they locked discussions into endless arguing about financial compensations. However, the game helped more consensual players distance themselves from these extremist views and advocate a more flexible approach to future negotiations. 
In contrast, some representatives of government agencies appeared to be virtual players, who felt that they were without any mandate for decisions that might represent the policies of their home institutions. As previously mentioned, only one player was part of the SAPHE Steering Committee; all others were not directly involved in the decision-making process regarding the water reserve issues. These players played a fair game but did not defend their agency's policy. Hence, the RPG was perceived only as a communication exercise.

Following this analysis, it was highly recommended that the next steps involve a sequential process for interactions. First, experts from the relevant government agencies should be confronted with a new version of the computer-based simulator, including most of the options in the existing flowchart. Experts would help select appropriate scenarios for the government and tune the parameters. Then, these scenarios should be presented in the different villages through collective meetings at which people would have the opportunity to interact with the computer simulations. Evaluation of the government criteria and scenarios would lead to the creation of newly modified ones. Finally, government experts and the island's representatives should meet again to assess the remaining options and attempt to reach equitable management scenario.

\section{Arm's-length debriefing}

At the end of May 2004, the project team returned to Tarawa to implement the sequential process. Soon after arrival, however, we were informed that the SAPHE Steering Committee had decided to organize meetings with the local communities on Tabiteuea and Abatao. The objective of these meetings was to present the design of the pumping galleries to the local residents and to seek for their agreement in principle. During separate meetings with members of the Steering Committee, the project team tried to underline the inherent risk in this hasty decision:

- The SAPHE Steering Committee relied on a design from a technical report (Falkland, 2003) that was not meant to be a final blueprint for implementation. The report carefully investigated the hydrogeological conditions prevailing on Abatao and Tabiteuea and provided some guidance in terms of positioning (distance to actual settlements) pumping galleries. Land ownership issues, population growth, and pollution control were not covered by this report.

- The SAPHE Steering Committee was unable to provide complete information to the local communities about financial arrangements, land-use constraints, or other compensation claims raised by some local residents. Beyond the local negotiation issue, these elements are fundamental in evaluating the economic viability of such a technological option. Falkland (2003) was very cautious regarding this specific aspect in his recommendations and indeed had recommended the exploitation of additional resources on Bonriki before the expansion to North Tarawa.

- The SAPHE Steering Committee had not taken into account the outcomes of the RPG workshop that provided a tentative road map for further negotiations, including financial and technical aspects. It was obvious that a direct confrontation would reignite the "water lease" issue. As well, the majority of residents on Abatao needed to be dealt with cautiously to avoid further damage. 


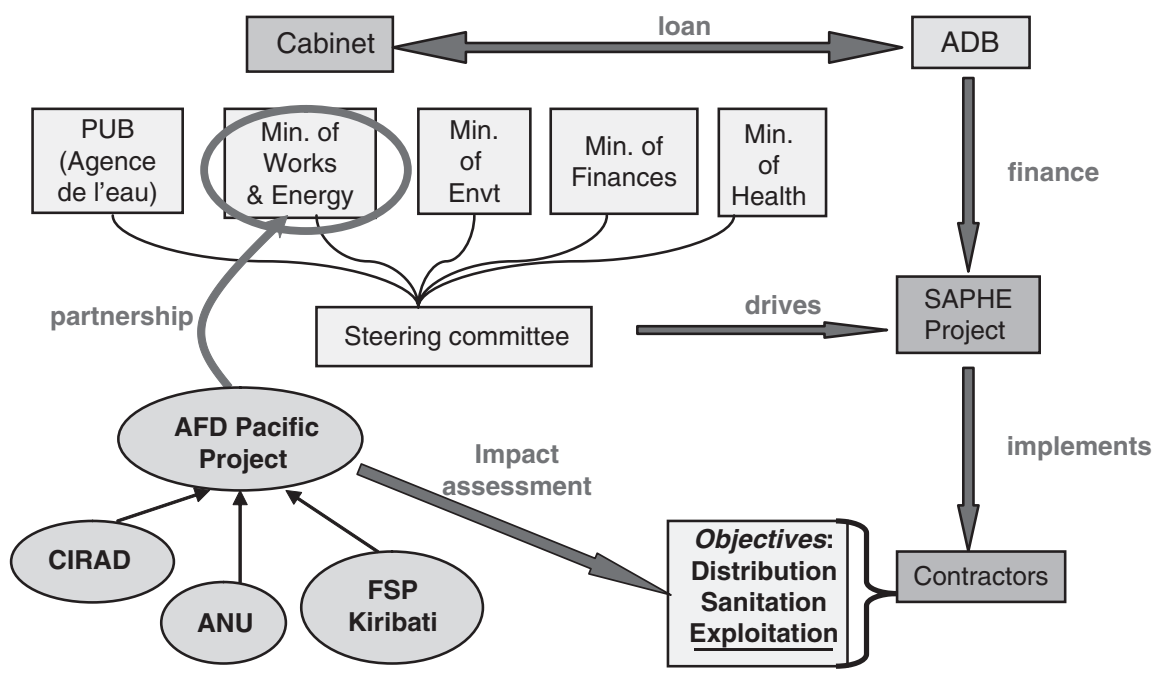

FIGURE 7: Local and Foreign Agencies Involved in the Sanitation, Public Health and Environment (SAPHE) Project

NOTE: $\mathrm{ADB}=$ Asian Development Bank; AFD = Agence Française de Développement; ANU = Australian National University; CIRAD = Centre de Cooperation Internationale en Recherche Agronomique Pour le Développement; Env ${ }^{t}=$ Environment; FSP $=$ Foundation for the Peoples of the South Pacific; Min. = Ministry; PUB = Public Utility Board.

Despite these concerns, the SAPHE meetings were confirmed, but the Steering Committee allowed the project team to attend the meetings as observers. As anticipated, the meetings held in Tabiteuea and Abatao would have benefited from a careful analysis and better understanding of the outcomes of the RPG workshop. Whether they agreed or disagreed with the proposed water reserves, local residents constantly referred to our final flowchart. These meetings resulted in a process in which a majority of local residents focused again on the financial compensation aspects of the question.

The reason for the Steering Committee's rejection of the RPG outcomes is partly to be found in the absence of crucial meta-players during the RPG sessions. As shown in Figure 7, the Asian Development Bank, the project contractor, and the government cabinet control the financial, technical, and political agendas of the SAPHE project. One year from the end of the loan-based project, technical delivery from the contractor became essential to secure the last payments. From the Asian Development Bank's perspective, the completion of the disbursement of funds was imperative. At the political level, the cabinet was entangled in multiple discussions with the Asian Development Bank and other funding agencies over other waterrelated projects. The SAPHE Steering Committee, instead of being a driving force, had become an arena for external and conflicting pressures. 
Despite the claims that (a) the results from the RPG were not detrimental to the SAPHE project and (b) further negotiations with local communities would need less than 6 months, the financial and technical agendas of the meta-players prevailed. Beyond the timing issue, the results of the RPG project may have been considered by some members of the Steering Committee as an acknowledgment of incapacity to tackle the problem in the first place.

The political uncertainty of the situation has been demonstrated by a decision to freeze the SAPHE project (October 2004), then to accept its implementation (January 2005) without modification, and finally to go ahead with the development of additional resources at Bonriki (May 2005). The consequences were that more than 6 months were lost in the process and that the local communities had not participated in the process. An interesting final twist is the actual willingness of PUB to resume collaboration with the research team to develop a more participatory approach in the future.

The struggle between centralized and decentralized management is epitomized in the concept of polycentric institutions developed by Ostrom (2004) in her most recent work. Technical agencies such as PUB very often rely on deductive scientific approaches to reach outcomes that require more inductive and flexible solutions. But flexibility means that one must assume some uncertainty during implementation and abandon reliance on deterministic and predictable solutions (Bradshaw \& Borchers, 2000). What is true at the technical level becomes paramount at the political level.

There is a pressing need for integrating not only the participation but, more important, the engagement of local communities in projects that concern their future. Following Aslin and Brown (2004), we argue that local communities need to be involved not only in the analysis of the results (consultation) or the choice of the possible scenarios (participation) but in the knowledge creation itself (engagement). This is the postnormal way chosen, for example, in companion modeling approaches (Bousquet et al., 2002).

\section{References}

Aslin, H. J., \& Brown, V. A. (2004). Towards whole of community engagement: A practical toolkit. Canberra, Australia: Murray-Darling Basin Commission.

Becu, N., Bousquet, F., Barreteau, O., Perez, P., \& Walker, A. (2003). A methodology for eliciting and modelling stakeholders' representations with agent based modelling. Lecture Notes in Artificial Intelligence, 2927, 131-149.

Bousquet, F., Bakam, I., Proton, H., \& Le Page, C. (1998). CORMAS: Common-pool resources and multi-agent systems. Lecture Notes in Artificial Intelligence, 1416, 826-837.

Bousquet, F., Barreteau, O., D’Aquino, P., Etienne, M., Boissau, S., Aubert, S., et al. (2002) Multi-agent systems and role games: Collective learning processes for ecosystem management. In M. A. Janssen (Ed.), Complexity and ecosystem management: The theory and practice of multi-agent systems (pp. 248-285). London: Edward Elgar.

Bradshaw, G. A., \& Borchers, J. G. (2000). Uncertainty as information: Narrowing the science-policy gap. Conservation Ecology, 4(1). Available at http://www.ecologyandsociety.org/vol4/iss1/art7/

Capenter, C., Stubbs, J., \& Overmars, M. (2002). Proceedings of the Pacific Regional Consultation on Water in Small Island Countries, Sigatoka, Fiji Islands, 29 July-3 August 2002. Manila, Philippines: Asian Development Bank. 
D’Aquino, P., Le Page, C., Bousquet, F., \& Bah, A. (2003) Using self-designed role-playing games and a multi-agent system to empower a local decision-making process for land use management: The SELFCORMAS experiment in Senegal. Journal of Artificial Societies and Social Simulation, 6(3). Available at http://jasss.soc.surrey.ac.uk/6/3/5.html

Descola, P. (1996). Constructing natures: Symbolic ecology and social practice. In P. Descola \& G. Palsson (Eds.), Nature and society: Anthropological perspectives (pp. 82-102). London: Routledge.

Dray, A., Perez, P., Jones, N., Le Page, C., D’Aquino, P., White, I., et al. (2006). The ATOLLGAME experience: From knowledge engineering to a computer-assisted role playing game. Journal of Artificial Societies and Social Simulation, 9(1). Available at http://jasss.soc.surrey.ac.uk/9/1/6.html

Falkland, A. C. (1992). Review of Tarawa freshwater lenses, Republic of Kiribati (Report 92/682). Canberra, Australia: Hydrology and Water Resources Branch, ACT Electricity and Water.

Falkland, A. C., \& Brunel, J. P. (1993). Review of hydrology and water resources of the humid tropical islands. In M. Bonell, M. M. Hufschmidt, \& J. S. Gladwell (Eds.), Hydrology and water management in the humid tropics (pp. 135-163). Cambridge, UK: Cambridge University Press.

Falkland, T. (2003). Review of groundwater resources management for Tarawa (Kiribati SAPHE Project: Mid-term review, Loan No. 1648-KIR [SF], Ecowise Environmental Report No. EHYD 2003/10). Manila, Philippines: Asian Development Bank.

Jones, P. (1997). The impact of the socio-cultural order on urban management in the Pacific: A case study of South Tarawa, Republic of Kiribati. Unpublished doctoral dissertation, Department of Geographical Sciences and Planning, University of Queensland, Australia.

Ostrom, E. (2005). Understanding institutional diversity. Princeton, NJ: Princeton University Press.

Perez, P., Dray, A., White, I., Le Page, C., \& Falkland, T. (2003). ATOLLSCAPE: Simulating freshwater management in Pacific atolls: Spatial processes and time dependence issues. In D. Post (Ed.), Proceedings of the International Congress on Modelling and Simulation (Vol. 4 pp. 514-518). Canberra, Australia: Integrated Catchment Assessment and Management Centre.

Volker, R. E., Mariño, M. A., \& Rolston, D. E. (1985). Transition zone width in groundwater on ocean atolls. Journal of Hydrological Engineering, 111, 659-676.

White, I., \& Falkland, A. (2004, November). Effects of pumping from infiltration galleries on crop health and production in low coral islands: Groundwater impacts. Canberra: Australian Centre for International Agricultural Research.

White, I., Falkland, A., Crennan, L., Jones, P., Etuati, B., Metai, E., et al. (1999). Issues, traditions and conflicts in groundwater use and management (UNESCO International Hydrological Programme, Humid Tropics Programme, IHP-V Theme 6, Technical Documents in Hydrology No. 25). Paris: UNESCO.

White, I., Falkland, T., Perez, P., Dray, A., Jones, P., Metutera, T., et al. (2002). An integrated approach to groundwater management and conflict reduction in low coral islands. In Proceedings of the International Symposium on Low-Lying Coastal Areas: Hydrology and integrated coastal zone management (pp. 249-256). Paris: UNESCO.

Anne Dray is a research fellow at the Australian National University (Canberra, Australia). Her work aims at developing agent-based models coupled with role-playing games to explore complex system dealing with natural resource management (groundwater exploitation in Kiribati, salinity control in Western Australia, and coral reef conservation in the Philippines and Mesoamerica). She is also involved in training courses for Australian students on the CORMAS platform.

Pascal Perez is currently seconded by the French research agency Centre de Cooperation Internationale en Recherche Agronomique Pour le Développement to the Australian National University (Canberra, Australia). He is the convenor of the Human Ecosystems Modelling With Agents international network. An agronomist by training, Dr. Perez's most recent work focuses on human ecosystems modeling. He has developed projects in northern Thailand, Indonesia, and Micronesia. He is currently teaching agentbased modeling techniques at the Australian National University. 
Christophe Le Page has a DEngr in fishery sciences and a PhD in biomathematics. He has been designing, implementing, and using agent-based simulations and role-playing games in the field of renewable resource management for 10 years. He is one of the developers of the CORMAS simulation platform (http://www .cormas.fr) and also an active member of the companion modeling network (http://www.commod.org).

Patrick D'Aquino is a director of research in social geography. For 10 years, he focused on the conception of supports to accompany decentralized processes within land-use planning, focusing on common resources. His concern is reconciling social geography and the development of technical tools adapted to local stakes and constraints. Focused on social processes and local knowledge for managing common resources, Dr. D'Aquino studied and assisted local organizations implementing and regulating land-use rights in the Sahelian zone of Africa. He now works in Pacific areas on geographic and other participatory modeling tools and on novel planning practices to support local organizations and social dynamics. He is interested in supports allowing people to progress in the interconnection between local and global decision processes.

Ian White is currently a professor of hydrology at the Australian National University (Canberra, Australia). He is a distinguished member of several international organizations, including the United Nations Educational, Scientific and Cultural Organization's International Hydrological Programme. $D r$. White's major research theme is the prediction and measurement of the downstream impacts of land use, including the acidification of coastal streams, modeling the groundwater dynamics of salinity and waste disposal schemes, the prediction of water use by trees, the sustainability of water extraction from shallow groundwater systems in coastal areas, and quantitative techniques for soil water measurement in the root and vadose zones at appropriate scales.

ADDRESSES: AD: Research School of Pacific \& Asian Studies, RMAP Program, Coombs Building, Australian National University, Canberra ACT 0200, Australia; telephone: +61(0)2-61-2522-37; e-mail: annedray@coombs.anu.edu.au.PP: CIRAD Australia, Research School of Pacific \& Asian Studies, RMAP Program, Room 5013, Coombs Building, Australian National University, Canberra ACT 0200, Australia; e-mail: pascal.perez@anu.edu.au. CLP: CU-CIRAD Project, Department of Biology, 254, Phayathai Road, Pathumwan, 10330 Bangkok, Thailand; e-mail: christophe.le_page@cirad.fr. PD: IAC, BP 06, 98825 Pouembout, Nouvelle Calédonie, France; e-mail: daquino@cirad.fr. IW: CRES, Hancock Building, Australian National University, Canberra, ACT 0200, Australia; e-mail: ian.white@anu.edu.au. 